\title{
Business Student Attitudes, Experience, And Satisfaction With Online Courses
}

\author{
Ann Kuzma, Minnesota State University, Mankato, USA \\ John Kuzma, Minnesota State University, Mankato, USA \\ Harold Thiewes, Minnesota State University, Mankato, USA
}

\begin{abstract}
The purpose of our study is to examine business students' perceptions of their online class experience relative to the traditional in-class experience; specifically, whether a descriptive, theoretical or analytical course would be preferred as an online or traditional course. Two hundred and ninety students enrolled in upper-level business courses were surveyed at a mid-level Association to Advance Collegiate Schools of Business accredited public university. Students were then asked to contrast their experiences with online and traditional classes regarding convenience, amount learned, difficulty, etc. A breakdown of the students by major revealed similar attitudes toward the online experience whether majoring in a more analytical or softskilled business discipline.
\end{abstract}

Keywords: Online Education; Student Attitudes; Student Experience; Student Satisfaction

\section{INTRODUCTION}

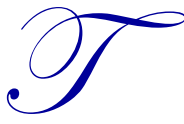

oday's educational environment has influenced and been transformed by the many non-profit and forprofit universities that offer online college courses for credit toward a degree. Online courses offer students the opportunity to complete classes without the physical constraints of having to go to a classroom, the geographical constraints of having to be in a certain location, and the time constraints of having to be available during a certain time frame. These conveniences have caused online class enrollments to dramatically increase. Many states are currently in economic stress over the enormous state expenditures connected to their various programs, not the least of which is funding for higher education. Due to facility and staffing constraints, many universities have turned to online educational delivery as a means to cope with the delivery of the needed courses.

\section{LITERATURE REVIEW}

Distance education, or distance learning, is certainly not a new educational technique. Correspondence courses, for example, in which students and teachers communicate by mail, were first offered several hundred years ago. Extended education or learning, referring to large universities setting up satellite or branch campuses, dates back over one hundred years. Online courses, which can be offered in a number of different ways, were first developed in the 1980s. CALCampus is a private, international, online distance institution which offers college and high school courses through the use of the internet and claims to have been the first to offer a completely online curriculum, in 1994 (CALCampus, 2014). In the two decades since, online classes have spread rapidly throughout the educational environment. A 2011 Pew Research Center study surveyed college presidents and found that $77 \%$ said their institution offered online courses. Half also said that they believe that most students at their schools will be enrolled in at least some online classes within the next ten years (Parker et al., 2011). This study also found that $23 \%$ of college graduates have taken a course online, with that figure rising to $46 \%$ for those who have graduated within the last decade (Parker et al., 2011.)

As the number of online course offerings continues to grow, the need to study this form of educational delivery grows as well. First of all, the term "online" takes on a number of different meanings depending on the 
institution offering the course. For some, students in online courses never have to step foot on campus, if indeed, there is a physical campus. For others, online courses might refer to a blend of face-to-face meetings - perhaps for lectures, exams, and student presentations - and online delivery throughout a term. This combination of the two delivery methods may be referred to as a hybrid, blended, or flipped course. McFarland and Hamilton (2005, 25) noted that:

...the definition of "online" varies widely and we can find no generally accepted definition. An "online" course can alternatively mean a course having materials delivered online that meets synchronously and regularly, to a course having materials delivered online that never meets synchronously, and the student learns completely independent of a live instructor, to a course delivered by videoconferencing, where a live instructor is lecturing in one location and students are viewing the lecture in another location.

Much of the early research in this area focused on the differences between online and face-to-face classroom teaching. For the most part, performance measures of student learning across disciplines found no significant differences in student learning (Arbaugh and Stelzer, 2003). Daymont and Blau (2008), controlling for factors such as class, major, and GPA, found that students in online undergraduate management courses performed as well as students in traditional courses. They also found that in online sections, females performed at least as well as males, reversing earlier findings that suggested that less computer usage and higher computer anxiety among women had created a gender gap. McFarland and Hamilton (2005) studied undergraduate MIS students with similar results. No difference in performance was found between students who studied online and students who studied in a traditional manner.

Subsequent research has focused on less concrete factors than performance. Studies of attitudes, perceptions, and satisfaction regarding online course instruction have examined the perspectives of students, faculty, administrators, and employers. In a study of graduate students enrolled in online courses, Song, Singleton, Hill, and Koh (2004) identified factors that impact the success of an online learning experience. These included course design, learner motivation, time management, and comfortableness with online technologies. Challenges to learning included such factors as technical problems, a perceived lack of community, time constraints, and difficulty in understanding the objectives of online courses. Tanner, Noser, and Totaro (2009) compared the attitudes and perceptions of business faculty who had taught online and business students who had taken online courses to faculty and students who had not taught or taken online courses. Both faculty and students felt that online classes require students to teach themselves and to be more disciplined than when in a traditional class. In general, faculty viewed online learning less favorably than students, questioning the level of learning and lack of interaction. In their study comparing administrator and faculty perceptions of online learning, Tanner, Noser, Totaro, and Bruno (2008) found significant differences on eight out of eighteen statements including: in the future our college should offer as many online courses as possible (faculty disagreed); face-to-face interaction outside the classroom is important for college classes (faculty agreed); and, a lack of interaction hinders the learning experiences (faculty agreed.) Astani and Ready (2010), in an exploratory study of employers, found that, overall, employers favor online learning due to the flexibility involved, but were uncertain about whether an online degree was comparable to a traditional face-to-face degree. Indeed, their results suggested concerns with opportunities for "teamwork" and "voicing opinion" in the online learning environment, both essential skills for success in business organizations.

Other research has attempted to determine if students who exhibit certain personality traits and learning styles will be more or less likely to succeed in an online learning situation. Daymont and Blau (2008) addressed this issue of student self-discipline in their study of undergraduates. Specifically, if students do not have the ability to self-motivate, they are less likely to succeed in online courses. Further, if a lack of self-discipline is perceived to be common among college students, this could have implications to colleges and programs attempting to expand their online offerings. Given the pressures that some program directors may be experiencing to increase online offerings, the result could be a re-structuring of online courses to accommodate these characteristics. For example, throughout a class period, a face-to-face instructor may provide numerous reminders to students regarding upcoming examinations and assignments. Online instructors may find it necessary to provide a similar experience through the use of emails and online announcements as a way to compensate for the lack of face-to-face interaction. McFarland and Hamilton (2005) also attempted to identify student factors which would contribute to performance and satisfaction. The majority of students in their study, however, indicated "convenience of the time period offered" 
rather than learning style or other motivations as the reason for choosing an online section rather than a face-to-face section of the same course.

Beginning in 2002, and administered on an annual basis, the Babson Survey Research Group, in partnership with the College Board, has collected data on the state of online learning in U. S. higher education from chief academic officers from more than 2,800 colleges and universities. In their first report, the Babson Survey found that $71.7 \%$ of higher education institutions provided some form of online offering, with $28.3 \%$ having no online courses at all (Allen and Seaman, 2013). Ten years later, in 2012, the number of institutions with no online has dropped to less than half of the 2002 value, at $13.5 \%$ (Allen and Seaman, 2013). In addition, the Babson Survey reported that the number of institutions offering complete online programs had increased from $34.5 \%$ in 2002 to $62.4 \%$ in 2012 (Allen and Seaman, 2013). Also in 2012, the U.S. Education Department estimated that 5.5 million students took at least one online course (Kolowich, 2014).

One of the major questions that the growth in online education raises is whether it places more demands on faculty. In other words, does it take more faculty time and effort to teach online? The Babson survey reported that in $201244.6 \%$ of academic leaders agreed that online classes do require more time and effort from faculty than corresponding face-to-face courses, compared to 40.7\% who agreed in 2006 (Allen and Seaman, 2013). Interestingly, academic leaders from for-profit institutions have moved in the opposite direction. When examined separately from public and nonprofit institutions, the leaders at for-profits who agreed that it takes more faculty time and effort to teach online decreased from 31.6\% in 2006 to 24.2\% in 2012 (Allen and Seaman, 2013). The Babson researchers speculated that for-profit institutions may have based much of their growth on online programs and thus have reached a level of optimization that the other institutions have not yet achieved.

Schmidt, Hodge, and Tschida (2013) addressed the readiness of faculty to teach online courses at a major southeastern university and the processes by which faculty learned how best to teach online. Some focus group participants reported that they often had to "jump right in" when they began teaching online courses, and had to learn on their own with little assistance from the university administration. Many reported that they considered their first experiences with online teaching to be failures in that they did not feel that their students were given meaningful learning experiences. At the same time, these instructors and their corresponding academic departments were hastily trying to get as many online courses and programs as possible on their schedules.

Crawford-Ferre and Wiest (2012) noted that many instructors new to online teaching received little to no training specific to this delivery mode. This is possibly one of the reasons for the continued resistance among many faculty members to accept online teaching assignments. The Babson Survey reported that between 2002 and 2012, the proportion of institutions reporting their faculty accept the value and legitimacy of online education increased by less than three percentage points, from $27.6 \%$ to $30.2 \%$ (Allen and Seaman, 2013). Over the same ten-year time period, however, the Babson survey found that the number of chief academic officers who considered online education to be critical to their long-term strategy increased from $48.8 \%$ in 2002 to $69.1 \%$ in 2012 (Allen and Seaman, 2013).

Over the last decade, the number of students who have taken at least one online course, according to the Babson survey, has grown from approximately 1.6 million to 7.1 million (Allen and Seaman, 2013). In the fall of 2011,32.0\% of total enrollment in degree-granting postsecondary institutions came from online enrollment (Allen and Seaman, 2013). These numbers indicate that online education is not a passing fad. Indeed, college administrators facing increasing economic challenges may view online course offerings not only as a way to widen their markets, but as a means to save money at the same time. O'Neill and Sai (2014) suggest that the physical plants of many public colleges and universities may also be factors contributing to the growth of online programs. Campus buildings constructed during the 1960s and 1970s - built to accommodate baby boomers - may be in need of major remodeling. College administrators, along with local government officials, may question the costs of a major infrastructure overhaul versus simply offering online courses that do not require "brick and mortar" facilities.

One area of research that has been largely overlooked pertains to certain aspects of student decision making with regard to online versus face-to-face classes. For example, why would students who have the option to take online courses choose instead to take face-to-face classes? O'Neill and Sai (2014) surveyed students enrolled in a 
face-to-face class which had a corresponding online course offered at the same tuition rate earning the same number of credits. Specifically, they were attempting to understand the motivations of those students who avoid online courses. They found that the majority of students believed that they would learn more by taking the course face-toface. While acknowledging that numerous studies have not shown significant differences in student learning between face-to-face and online courses, O'Neill and Sai (2014) suggest that student perceptions of what was learned should be a consideration when designing and then offering online courses. These perceptions could be crucial years later, when students who were "forced" into online courses, are contacted by alumni organizations for the purpose of fund-raising. Black, Dawson, and Ferdig (2006) refer to online graduates as the "forgotten alumni" of university advancement. While the expectation of future donations should not necessarily be the driving force behind curriculum development, this does suggest that online education impacts many areas of higher education and administration.

Many institutions may indeed be finding themselves in the situation of having to decide whether to offer required courses as face-to-face or online because they do not have the resources to offer both formats. College students select their universities based on a number of factors, including quality of instruction and faculty reputation. It is not outside of the realm of possibility that between the time that a student is accepted at a school and when he/she graduates a few years later, that student might have to take many online courses because face-to-face versions are no longer offered by that same institution. What are the implications of this situation? One outcome is student dissatisfaction with his or her education and with the institution in general. Students who believe that they learn more through face-to-face may suspect that they were given an inferior education even though numerous studies show no significant difference (McFarland and Hamilton, 2005; Daymont and Blau, 2008, Arbaugh and Stelzer, 2013). There appear to be no studies, however, that have attempted to compare the experiences of those students who enrolled in an online course because the traditional course was not available to those students who voluntarily enrolled in an online course.

\section{THE STUDY}

In the attempt to better understand the student learning process, we surveyed 290 students that were enrolled in upper-level business courses at a mid-level AACSB accredited Midwestern university during the fall semester of 2013. Specifically, we asked students to report their experiences and perceptions of the traditional class room course experience versus the online course experience. Since Arbaugh and Seltzer (2003), Daymont and Blau (2008), McFarland and Hamilton (2005), and DiRienzo and Lilly (2014) all found no significant differences in the learning outcomes between traditional and online courses, we chose to examine the reasons students selected online classes and their perceptions of their experiences in those online classes. Of the 290 students surveyed, 254 (88\%) reported that they had enrolled in at least one online course prior to their junior year. Additionally, 225 (89\%) of the 254 students who had taken an online course took the course during the same semester in which they were taking a traditional, face-to-face course.

In terms of the number of online courses taken, 198 (78\%) of the 254 students reported that they had enrolled in four or less online courses during their collegiate career. In terms of the two extremes, 101 (40\%) reported that they had taken only one or two online courses while one student reported having taken 12 and another student reported they had taken 18 online courses during their academic career. Since 225 of the students enrolled in an online course during the same semester in which they were enrolled in traditional courses, we asked students to list the reasons why they selected an online course over the traditional course. The main reasons selected are presented in Table 1. Convenience and the lack of availability of the course offered as a traditional course were cited as the main reasons for enrolling in the online course. A smaller percentage, $43 \%$, listed scheduling conflict as another reason for enrolling in the course. Approximately one third took the course online because it was required and the online experience seemed easier but only a small percentage, $12 \%$, selected the online course because of the particular instructor who was teaching the course. 
Table 1: Reason You Enrolled In An Online Course As Opposed To A Traditional Course

\begin{tabular}{lc}
\hline \multicolumn{1}{c}{ Reason } & \# Selected (\% of 254 students enrolled in online course) \\
\hline Convenience (Employment, Family, etc.) & $138(54 \%)$ \\
Course Not Offered as a Traditional Course & $128(50 \%)$ \\
Traditional Course Conflicted with Another Course & $110(43 \%)$ \\
A Required Course and Online Course Seemed Easier & $87(34 \%)$ \\
Chose Online Course Because of Instructor Preference & $30(12 \%)$ \\
\hline
\end{tabular}

The next set of questions concerned the type of class students perceived to be more difficult when taken online. We separated the course content into three general categories: heavily descriptive, theoretical or analytical. We also wanted to determine if the students' business major would influence their opinion. The primary business major breakdown was as follows: 95 Marketing, 37 Management, 5 International Business, 72 Finance and 39 Accounting majors. For purposes of this comparative analysis, we created two samples: one that included the Marketing, Management, and International Business majors (hereafter, MMI) and the other including the Finance and Accounting majors (hereafter, FA). Rationale for this breakdown was due to the more analytical nature of the finance and accounting subjects and that certain students declared double majors in Accounting and Finance or Marketing and International Business; however, only the primary major is reported in the above breakdowns. If a student failed to properly rank the three alternatives such as ranking two or three of the alternatives with the same number, that response was eliminated from the analysis. This resulted in samples of $113 \mathrm{MMI}$ and $89 \mathrm{FA}$ students with accurate answers to this question. Students who declared business as a major were separated into two samples which is explained later in this paragraph. Those students declaring majors such as economics, construction, sports management, etc. formed a third sample, termed Other; 16 students were included in this Other sample. However, only the arithmetic means of the MMI and FA samples are used for comparative purposes.

Results are presented in Table 2. Overall, $66 \%$ of the students felt that courses involving a great amount of description or terminology could more easily be taken online, while those courses involving a high level of theory $(46 \%)$ or analytics (54\%) would be the most difficult to take online. Overall, all three samples were in agreement with this difficulty scaling. T-tests were conducted between the two business major samples for each of the three course types. There was no significant difference between the two business student samples on question 1-taking an online descriptive course ( $\mathrm{t}=.047)$, and question 3 - taking an analytical course $(\mathrm{t}=.93)$. Both were below the 5\% critical value of 1.97. However, a significant difference was observed between the two samples concerning the ease of taking a course online if it involved a high degree of theory. Overall, $90 \%$ of the total sample felt a theoretical course would be of moderate or the most difficult to take online, but a higher percentage, $57 \%$, in the FA sample (mean score $=2.49$ ) felt a theoretical course would be more difficult to take online relative to $28 \%$ of the MMI majors (mean score $=2.29$ ). This difference resulted in a t-value of 2.21 , significant at the .05 level. This result was somewhat surprising but may be attributed to the students' perception of how theory applied to their major. Thus, with the exception cited, overall, business students felt that descriptive courses could best be served online while theoretical or analytical courses would be the most difficult to be delivered properly online.

Table 2: Difficulty In Understanding Course Material If Online (1: Easiest To Learn On Line; 3: Most Difficult)

\begin{tabular}{|c|c|c|c|c|c|}
\hline Course Description & & 1: Easiest & 2: Moderate & 3: Most Difficult & Means \\
\hline Course Involving a Great Deal of & MMI* & $74(65 \%)$ & $19(17 \%)$ & $20(18 \%)$ & 1.522 \\
\hline Description or Terminology (i.e., & FA* & $59(66 \%)$ & $14(16 \%)$ & $16(18 \%)$ & 1.517 \\
\hline \multirow{2}{*}{ Biology or History) } & Other* & $11(69 \%)$ & $4(25 \%)$ & $1(6 \%)$ & $\mathrm{t}=.047$ \\
\hline & Total* & $144(66 \%)$ & $37(17 \%)$ & $37(17 \%)$ & \\
\hline Courses Involving a High Degree of & MMI & $12(10 \%)$ & $56(50 \%)$ & $45(28 \%)$ & 2.292 \\
\hline \multirow[t]{3}{*}{ Theory (i.e., Economics) } & FA & $7(8 \%)$ & $31(35 \%)$ & $51(57 \%)$ & 2.494 \\
\hline & Other & $3(19 \%)$ & $7(44 \%)$ & $\underline{6(38 \%)}$ & $\mathrm{t}=-2.21 * *$ \\
\hline & Total & $22(10 \%)$ & $94(44 \%)$ & $102(46 \%)$ & \\
\hline Course Involving a High Degree of & MMI & $17(15 \%)$ & $32(28 \%)$ & $64(57 \%)$ & 2.42 \\
\hline \multirow[t]{3}{*}{ Analytics (i.e., Statistics) } & FA & $16(18 \%)$ & $31(35 \%)$ & $42(47 \%)$ & 2.31 \\
\hline & Other & $1(6 \%)$ & $4(25 \%)$ & $11(69 \%)$ & $\mathrm{t}=.928$ \\
\hline & Total & $34(16 \%)$ & $67(30 \%)$ & $117(54 \%)$ & \\
\hline
\end{tabular}

*MMI is comprised of 113 Marketing, Management and International Business majors; FA is comprised of 89 Finance and Accounting majors; Other is comprised of 16 non-business majors: Total $=218$. The $\%$ is based on the number of each sample that ranked their response as 1(Easiest), 2(Moderate) or 3(Most Difficult).

**Average response and t-statistics are reported for the MMI and FA samples. Difference significant at the .05 level. 
We next asked students who had taken an online course to rate their experience relative to that of a traditional course. Students were asked to rate, on a 1 (Strongly Agree) to 5 (Strongly Disagree) Likert scale, certain factors considered important in the student learning experience. The statements and the results are presented in Table 3. For purposes of the discussion, the total number of students and/or percentages that either strongly agree/agree or disagree/strongly disagree will be aggregated as either agree or disagree, respectively. The reader can refer to the tables to see the number that had strongly or simply agreed/disagreed with the statement. The strongest disagreement resulted from statement $b$, that more was learned from online courses than the traditional courses. One hundred sixty seven $(66 \%)$ of the students disagreed with the statement that they learned more from online courses while only $33(16 \%)$ felt they learned more from the online experience. Question d, I learn more in traditional classes was also asked to gauge the consistency of student's answers with question b. One hundred and seventythree $(68 \%)$ of students felt they learned more in the traditional class while only $10 \%$ disagreed with the statement, thus confirming the consistency of the traditional class providing a stronger learning experience, in the student's opinion. Students were in general disagreement with statement a, that online courses are best for required courses. This response is likely motivated by the students' perception of the importance of the knowledge gained in required courses and the need to take these courses as traditional courses in which they believe they would learn more. However, even though $119(47.4 \%)$ students agreed, as opposed to $70(27.7 \%)$ disagreeing with the statement that online course requirements are less rigorous, almost half (48\%) agreed that online classes should be an option for all majors. Arbaugh and Seltzer (2003), Daymont and Blau (2008), McFarland and Hamilton (2005), and DiRienzo and Lilly (2014) all found no significant differences in the learning outcomes between traditional and online courses, Arbaugh and Seltzer (2003), Daymont and Blau (2008), McFarland and Hamilton (2005), and DiRienzo and Lilly (2014) all found no significant differences in the learning outcomes between traditional and online courses.

Table 3: Student rating of the online course experience

\begin{tabular}{|c|c|c|c|c|c|c|}
\hline Statement & $\begin{array}{c}1 \\
\text { Strongly Agree }\end{array}$ & $\begin{array}{c}2 \\
\text { Agree } \\
\end{array}$ & $\begin{array}{c}3 \\
\text { No Opinion } \\
\end{array}$ & $\begin{array}{c}4 \\
\text { Disagree } \\
\end{array}$ & $\begin{array}{c}5 \\
\text { Strongly Disagree } \\
\end{array}$ & $\begin{array}{c}\text { Average } \\
\text { Rating }\end{array}$ \\
\hline $\begin{array}{l}\text { a. Online Courses are best for } \\
\text { required courses }\end{array}$ & $\begin{array}{c}11 \\
(4.3 \%) \\
\end{array}$ & $\begin{array}{c}31 \\
(12.2 \%) \\
\end{array}$ & $\begin{array}{c}79 \\
(31.1 \%) \\
\end{array}$ & $\begin{array}{c}71 \\
(30.0 \%) \\
\end{array}$ & $\begin{array}{c}62 \\
(24.4 \%) \\
\end{array}$ & 3.56 \\
\hline $\begin{array}{l}\text { b. I learn more from online } \\
\text { than traditional courses }\end{array}$ & $\begin{array}{c}11 \\
(4.3 \%) \\
\end{array}$ & $\begin{array}{c}22 \\
(8.6 \% \\
\end{array}$ & $\begin{array}{c}54 \\
(21.2 \%) \\
\end{array}$ & $\begin{array}{c}79 \\
(31.1 \%) \\
\end{array}$ & $\begin{array}{c}88 \\
(34.6 \%) \\
\end{array}$ & 3.83 \\
\hline $\begin{array}{l}\text { c. I achieve higher grades } \\
\text { from online courses }\end{array}$ & $\begin{array}{c}52 \\
(20.5 \%) \\
\end{array}$ & $\begin{array}{c}70 \\
(27.5 \%) \\
\end{array}$ & $\begin{array}{c}72 \\
(28.3 \%) \\
\end{array}$ & $\begin{array}{c}38 \\
(15.0 \%) \\
\end{array}$ & $\begin{array}{c}22 \\
(8.7 \%) \\
\end{array}$ & 2.64 \\
\hline $\begin{array}{l}\text { d. I learn more in traditional } \\
\text { classes }\end{array}$ & $\begin{array}{c}94 \\
(37.0 \%) \\
\end{array}$ & $\begin{array}{c}79 \\
(31.1 \%) \\
\end{array}$ & $\begin{array}{c}54 \\
(21.3 \%) \\
\end{array}$ & $\begin{array}{c}24 \\
(9.4 \%) \\
\end{array}$ & $\begin{array}{c}3 \\
(1.2 \%) \\
\end{array}$ & 2.07 \\
\hline $\begin{array}{l}\text { e. Online course require- } \\
\text { ments are less rigorous }\end{array}$ & $\begin{array}{c}34 \\
(13.4 \%) \\
\end{array}$ & $\begin{array}{c}86 \\
(34.0 \%) \\
\end{array}$ & $\begin{array}{c}63 \\
(24.9 \%) \\
\end{array}$ & $\begin{array}{c}48 \\
(19.0 \% \\
\end{array}$ & $\begin{array}{c}22 \\
(8.7 \%) \\
\end{array}$ & 2.75 \\
\hline $\begin{array}{l}\text { f. Online classes should be an } \\
\text { option for all courses }\end{array}$ & $\begin{array}{c}70 \\
(27.7 \%) \\
\end{array}$ & $\begin{array}{c}51 \\
(20.2 \%) \\
\end{array}$ & $\begin{array}{c}56 \\
(22.1 \%) \\
\end{array}$ & $\begin{array}{c}50 \\
(19.8 \%) \\
\end{array}$ & $\begin{array}{c}26 \\
(10.3 \%) \\
\end{array}$ & 2.64 \\
\hline
\end{tabular}

We also felt that students who enrolled in an online course because the traditional course was not available might have different views than those students who voluntarily enrolled in the online course. A comparison of the 128 students who enrolled in online courses due to a lack of the traditional courses' availability revealed virtually identical proportions of agreement and disagreement to the six questions in Table 3. A chi square test between these 128 students and the total sample resulted in a chi square value of 13.17 , well below the required 31.4 critical value $(\alpha=.05$ and 20 degrees of freedom) required to reject the null of proportional similarity.

Lastly, all 290 students surveyed were asked to offer their views concerning various statements regarding online courses. Row totals do not all equal 290 due to failure of some students to rate all of the statements. The statements and average responses are reported in Table 4. Again, a Likert scale, ranging from 1 (Strongly Agree) to 5 (Strongly Disagree) was used. Our first set of statements, a through e, involved the students' perceptions of statements of comparison between online versus traditional classes. The second set of statements, $f$ through $g$, involved the students' perceptions of the convenience afforded by online classes. Lastly, the third set of statements involved the students' perceptions of the availability and scope of online classes that they would like to see available at the university. 
Again, for purposes of this discussion, the total number of students and/or percentages that either strongly agree/agree or disagree/strongly disagree will be aggregated as either agree or disagree, respectively. There was no strong consensus with the statement that online courses were easier than traditional courses with $42 \%$ agreeing and $27 \%$ disagreeing with the statement. Not surprisingly, there was strong agreement (73\%) that online courses allow students to work at their own pace. Unfortunately, slightly over half of the students felt the online experience made it easier to cheat on exams and that the online experience resulted in less learning (50\% agreeing versus $24 \%$ disagreeing). Approximately one quarter of the students had no opinion on these two statements. Not surprisingly, $78 \%$ of the students agreed with the statement that online courses were more convenient to take than traditional classes. This led us to our next set of questions concerning which convenience characteristic students rated the highest. In terms of the set of convenience statements, $86 \%$ like the convenience in scheduling of the online courses since they did not conflict with taking traditional courses, $78 \%$ liked the convenience of not having to travel to campus, and $71 \%$ liked online courses since they would not conflict with their work schedule. This result may suggest that course availability and scheduling conflicts may be of strongest concern to most students; specifically, $64 \%$ agreed that course availability is more important whether the course is online or traditional.

Table 4: Overall Student Attitudes of Online Education Content and Scheduling

\begin{tabular}{|c|c|c|c|c|c|c|}
\hline Statement & $\begin{array}{c}1 \\
\text { Strongly Agree }\end{array}$ & $\begin{array}{c}2 \\
\text { Agree }\end{array}$ & $\begin{array}{c}3 \\
\text { No Opinion }\end{array}$ & $\begin{array}{c}4 \\
\text { Disagree }\end{array}$ & $\begin{array}{c}5 \\
\text { Strongly Disagree }\end{array}$ & $\begin{array}{c}\text { Average } \\
\text { Rating }\end{array}$ \\
\hline \multicolumn{7}{|l|}{ I. Online classes ... } \\
\hline $\begin{array}{l}\text { a. Are easier than } \\
\text { traditional classes }\end{array}$ & $\begin{array}{c}28 \\
(10.1 \%)\end{array}$ & $\begin{array}{c}89 \\
(32.2 \%)\end{array}$ & $\begin{array}{c}85 \\
(30.8 \%)\end{array}$ & $\begin{array}{c}54 \\
(19.6 \%)\end{array}$ & $\begin{array}{c}30 \\
(7.2 \%)\end{array}$ & 2.82 \\
\hline $\begin{array}{l}\text { b. Allow you to work at } \\
\text { your own pace }\end{array}$ & $\begin{array}{c}93 \\
(33.7 \%)\end{array}$ & $\begin{array}{c}108 \\
(39.1 \%)\end{array}$ & $\begin{array}{c}31 \\
(11.2 \%)\end{array}$ & $\begin{array}{c}36 \\
(13.0 \%)\end{array}$ & $\begin{array}{c}7 \\
(2.5 \%)\end{array}$ & 2.11 \\
\hline $\begin{array}{l}\text { c. Make it easier to cheat } \\
\text { on exams }\end{array}$ & $\begin{array}{c}61 \\
(22.1 \%)\end{array}$ & $\begin{array}{c}78 \\
(28.3 \%)\end{array}$ & $\begin{array}{c}75 \\
(27.2 \%)\end{array}$ & $\begin{array}{c}40 \\
(14.5 \%)\end{array}$ & $\begin{array}{c}22 \\
(8.0 \%)\end{array}$ & 2.58 \\
\hline $\begin{array}{l}\text { d. Result in less learning } \\
\text { than traditional classes }\end{array}$ & $\begin{array}{c}48 \\
(17.4 \%) \\
\end{array}$ & $\begin{array}{c}89 \\
(32.2 \%) \\
\end{array}$ & $\begin{array}{c}72 \\
(26.1 \%) \\
\end{array}$ & $\begin{array}{c}57 \\
(20.7 \%) \\
\end{array}$ & $\begin{array}{c}10 \\
(3.6 \%) \\
\end{array}$ & 2.61 \\
\hline $\begin{array}{l}\text { E. Are more convenient } \\
\text { than traditional classes }\end{array}$ & $\begin{array}{c}117 \\
(42.4 \%)\end{array}$ & $\begin{array}{c}97 \\
(35.1 \%)\end{array}$ & $\begin{array}{c}39 \\
(14.1 \%)\end{array}$ & $\begin{array}{c}17 \\
(6.2 \%)\end{array}$ & $\begin{array}{c}6 \\
(21.7 \%)\end{array}$ & 1.91 \\
\hline \multicolumn{7}{|c|}{ II. Online classes are more convenient because they do not.... } \\
\hline $\begin{array}{l}\text { f. Require travel to } \\
\text { campus }\end{array}$ & $\begin{array}{c}104 \\
(37.8 \%)\end{array}$ & $\begin{array}{c}111 \\
(40.4 \%)\end{array}$ & $\begin{array}{c}45 \\
(16.4 \%)\end{array}$ & $\begin{array}{c}8 \\
(2.9 \%)\end{array}$ & $\begin{array}{c}7 \\
(2.5 \%)\end{array}$ & 1.92 \\
\hline $\begin{array}{l}\text { g. Conflict with traditional } \\
\text { classes }\end{array}$ & $\begin{array}{c}132 \\
(48.0 \%)\end{array}$ & $\begin{array}{c}104 \\
(37.8 \%)\end{array}$ & $\begin{array}{c}24 \\
(8.7 \%)\end{array}$ & $\begin{array}{c}8 \\
(2.9 \%)\end{array}$ & $\begin{array}{c}7 \\
(2.5 \%)\end{array}$ & 1.74 \\
\hline $\begin{array}{l}\text { h. Conflict with my work } \\
\text { schedule }\end{array}$ & $\begin{array}{c}93 \\
(33.8 \%) \\
\end{array}$ & $\begin{array}{c}102 \\
(37.1 \%) \\
\end{array}$ & $\begin{array}{c}54 \\
(19.6 \%) \\
\end{array}$ & $\begin{array}{c}18 \\
(6.5 \%) \\
\end{array}$ & $\begin{array}{c}8 \\
(2.9 \%) \\
\end{array}$ & 2.08 \\
\hline \multicolumn{7}{|l|}{ III. General } \\
\hline $\begin{array}{l}\text { i. Course availability is } \\
\text { more important whether } \\
\text { online or traditional }\end{array}$ & $\begin{array}{c}86 \\
(31.3 \%)\end{array}$ & $\begin{array}{c}90 \\
(32.7 \%)\end{array}$ & $\begin{array}{c}61 \\
(22.2 \%)\end{array}$ & $\begin{array}{c}29 \\
(10.5 \%)\end{array}$ & $\begin{array}{c}9 \\
(3.3 \%)\end{array}$ & 2.22 \\
\hline $\begin{array}{l}\text { j. I would prefer that all of } \\
\text { my cob courses were } \\
\text { online }\end{array}$ & $\begin{array}{c}18 \\
(6.5 \%)\end{array}$ & $\begin{array}{c}26 \\
(9.5 \%)\end{array}$ & $\begin{array}{c}64 \\
(23.3 \%)\end{array}$ & $\begin{array}{c}68 \\
(24.7 \%)\end{array}$ & $\begin{array}{c}99 \\
(36.0 \%)\end{array}$ & 3.74 \\
\hline $\begin{array}{l}\mathrm{k} . \text { I would prefer that all } \\
\text { of my cob courses were } \\
\text { traditional }\end{array}$ & $\begin{array}{c}57 \\
(20.8 \%)\end{array}$ & $\begin{array}{c}61 \\
(22.3 \%)\end{array}$ & $\begin{array}{c}80 \\
(29.2 \%)\end{array}$ & $\begin{array}{c}62 \\
(22.6 \%)\end{array}$ & $\begin{array}{c}14 \\
(5.1 \%)\end{array}$ & 2.69 \\
\hline $\begin{array}{l}\text { 1. Hybrid courses are a } \\
\text { better option than } 100 \% \\
\text { online or traditional }\end{array}$ & $\begin{array}{c}47 \\
(17.2 \%)\end{array}$ & $\begin{array}{c}68 \\
(24.8 \%)\end{array}$ & $\begin{array}{c}98 \\
(35.8 \%)\end{array}$ & $\begin{array}{c}37 \\
(13.5 \%)\end{array}$ & $\begin{array}{c}24 \\
(8.6 \%)\end{array}$ & 2.72 \\
\hline
\end{tabular}

Only $16 \%$ agreed while $61 \%$ disagreed with the statement that they would like to take all of their COB courses online. When asked if they would prefer to take all of their courses as traditional courses, $43 \%$ agreed while only $28 \%$ disagreed with the statement. Thus, there seems to be a decided preference to take courses as traditional rather than online. This may fly in contrast to many university objectives, due to cost advantages, to encourage academic departments to offer their entire majors online. Lastly, we asked students feelings of hybrid courses.

This statement resulted in the highest percentage of 'no opinion' responses, possibly due to the variability in what a hybrid course might entail. 


\section{CONCLUSIONS AND IMPLICATIONS}

We examined students enrolled in business courses to determine their perceptions of their online experience. Various reasons were cited by students for taking the online course and, consistent with the McFarland and Hamilton (2005) study, factors relating to convenience were cited as the main reason students selected the online course. There was only moderate agreement that online course requirements were less demanding and the grading was more lenient than traditional classes. Previous studies, specifically Arbaugh and Seltzer (2003), Daymont and Blau (2008), McFarland and Hamilton (2005), and DiRienzo and Lilly (2014), found no significant differences in the learning outcomes between traditional and online courses. However, students' perceptions indicate that they feel that they learn more in traditional than online classes and, as O'Neill and Sai (2014) suggest, student perceptions of learning should be considered when designing online courses.

Students feel that courses whose content deals with more descriptive terminology or memorization are more suited for online classes than courses whose content is more analytical or theoretical. The DiRienzo and Lilly (2014) study found no significant differences in student performance on both basic applications and complex assignments but student responses from our study suggests that business students feel they receive more clarity when theoretical or analytical information is presented in a face-to-face situation. This finding is consistent across all of the business students, regardless of the declared major. Many students stated that they selected the online course because that particular course was not offered as a traditional course. Although one might expect a less favorable attitude among these business students to the online experience, we found that the attitudes of this group were not significantly different from students who voluntarily selected the online course, even though a traditional class was available.

The economic environment has resulted in reductions in many university budgets. Thus, administrators must try to do more with fewer resources. They will try to serve more students with less infra-structure (i.e. classrooms.) In this endeavor, administrators will continue to leverage their efforts to increase the amount of online class offerings. However, Allen and Seaman (2013) found that in 2012 a higher percentage of academic leaders agreed that online classes required more time and effort from faculty than corresponding face-to face classes. Crawford-Ferre and Wiest (2012) and Schmidt, Hodge, and Tschida (2013) indicated that instructors and faculty new to online teaching received little to no training in this delivery method and had to learn on their own without assistance from the university administration.

\section{AUTHOR INFORMATION}

Dr. Ann Kuzma received her Ph.D. in Marketing from Kent State University in 1989. She has taught at Minnesota State University, Mankato from 1989 until the present and has previously served as the Chairperson for the Department of Marketing and International Business. E-mail: ann.kuzma@ mnsu.edu

Dr. John Kuzma received his Ph.D. in Marketing from Kent State University in 1990. He has taught at Minnesota State University, Mankato from 1989 until the present. E-mail: john.kuzma@ mnsu.edu (contact author)

Dr. Harold Thiewes received his Ph.D. in Finance from the University of Iowa in 1990. He has taught at Minnesota State University, Mankato and the University of Iowa from 1980 until the present and has previously served as the Chairperson for the Department of Finance. E-mail: harold.thiewes@mnsu.edu

\section{REFERENCES}

Allen, I. Elaine \& Seaman, J. (2013). Changing course: Ten years of tracking online education in the United States. Babson Survey Research Group and Quahog Research Group, LLC.

Arbaugh, J., \& Stelzer, L. (2003). Learning and Teaching Management on the Web: What do we know? Educating Managers with Tomorrow's Technologies (pp. 17-51). Information Age Publishing, Inc.

Astani, M., \& Ready, K. (2010). Employers' perceptions of online versus traditional face-to-face learning. The Business Review, Cambridge, 16(2), 91-96. 
Black, E., Dawson, K. \& Ferdig, R. (2006). Forgotten alumni: Online learners as donors. Academic Exchange Quarterly, 10(1), 43-47.

CALCampus - About. (n.d.). CALCampus - About. Retrieved August 1, 2014, from http://www.calcampus.com/about.htm.

Crawford-Ferre, H., \& Wiest, L. (2012). Effective online instruction in higher education. The Quarterly Review of Distance Education, 13(1), 11-14.

Daymont, T., \& Blau, G. (2008). Student performance in online and traditional sections of an undergraduate management course. Journal of Behavioral and Applied Management, 9(3), 275-294.

DiRienzo, C. \& Lilly, G. (2014). Online versus face-to-face: Does delivery method matter for undergraduate business school learning?, BusinessEducation \& Accreditation, 6(1),1-11.

Kolowich, S. (2014, January 16). Exactly how many students take online courses? The Chronicle of Higher Education. Retrieved October 31, 2014, from http://chronicle.com/blogs/wiredcampus/exactly-how-manystudents-take-online-courses/49455

McFarland, D., \& Hamilton, D. (Winter 2005/2006). Factors affecting student performance and satisfaction: online versus traditional course delivery. The Journal of Computer Informational Systems, 46(2), 25-32.

O’Neill, K. \& Sai, T. (2014). Why not? Examining college students' reasons for avoiding an online course. Higher Education, 68, 1-14.

Parker, K., Lenhart, A., \& Moore, K. (2011). The digital revolution and higher education: college presidents, public differ on value of online learning. Retrieved November 7, 2014 from http://www.pewinternet.org/2011/08/28/the-digital-revolution-and-higher-education/

Schmidt, S., Hodge, E., \& Tschida, C. (2013). How university faculty members developed their online teaching skills. The Quarterly Review of Distance Education, 14(1), 131-140.

Song, L., Singleton, E., Hill, J., \& Koh, M. (2004). Improving online learning: student perceptions of useful and challenging characteristics. Internet and Higher Education, 7, 59-70.

Tanner, J., Noser, T., \& Totaro, M. (2009). Business faculty and undergraduate students' perceptions of online learning: a comparative study. Journal of Informational Systems Education, 20(1), 29-40.

Tanner, J., Noser, T., Totaro, M., \& Bruno, M. (2008). Business school administrators' and faculty perceptions of online learning: a comparative study. Proceedings of the Allied Academies, 15(2), 137-141. 
NOTES 